\title{
Effects of sticky rice addition on the properties of lime-tile dust mortars
}

\author{
Kun Zhang ${ }^{1,2}$, Ying Sui ${ }^{1,2}$, Liqin Wang ${ }^{1,2}$, Fude Tie ${ }^{1,2,3}$, Fuwei Yang ${ }^{1,2^{*}}$, Yan Liu ${ }^{1,2}$ and Yue Zhang ${ }^{4}$
}

\begin{abstract}
The present study focused on the characteristics of lime-tile dust mortars with sticky rice addition, which were prepared according to historic Chinese accounts. Results showed that addition of sticky rice into mortars could improve water retention capacity, prolong setting time, and reduce bulk density values. Sticky rice addition also had long-term detrimental impacts on mortar strength development, concurrently increasing their water absorption values. FTIR, XRD and TG-DSC analyses revealed that the addition of sticky rice into mortars could slow down the carbonation as well as hydration process, at the same time forming both calcite and aragonite as carbonation products.
\end{abstract}

Keywords: Mortar, Organic additive, Sticky rice, Analysis, Mechanism

\section{Introduction}

Sticky rice, also known as glutinous rice or waxy rice, is a type of rice mainly grown in East and Southeast Asia, characterized by its opaque appearance, high amylopectin content and sticky texture. Apart from being a staple food in China, sticky rice was widely applied in various other fields including architectural construction. For instance, many historic Chinese literatures accounted the use of lime-sticky rice mortars to build river dams [1], barns [2], flood gates [3] and tombs [4]. Sticky rice porridge was also commonly added in lime-clay-sand mortars to build forts [5] and Fujian Tulou (Hakka earth buildings) [6, 7].

Relevant studies have reported the effects and mechanism of sticky rice addition in air lime mortars. Yang et al. [8] found that sticky rice could significantly improve mechanical strengths and compatibility of air lime mortars and control the growth of $\mathrm{CaCO}_{3}$ crystals. Zhao et al. [9] reported that the addition of sticky rice porridge at $5 \%-\mathrm{w} / \mathrm{w}$ in air lime mortars could accelerate mortar setting and hardening, increase compressive and bonding strength, at the same time slightly reducing mortar

\footnotetext{
*Correspondence: yangfwnwu@163.com

1 School of Cultural Heritage, Northwest University, Xuefu Avenue 1, Xi'an 710000, China

Full list of author information is available at the end of the article
}

density and water resistance. Zhang et al. [10] reported that the mechanical strengths of lime-sticky rice mortars can be significantly decreased by cyclic wetting-drying and dilute sulfate acid actions, causing more porous matrices and coarser particles. Yang et al. [11] concluded that sticky rice addition could induce pronounced heterogeneity in mortars, leading to inhomogeneous strain field and produce micro-cracks during wetting-drying cycles. The results of Zeng et al. [12] showed that biomineralization may occur in lime-sticky rice mortars, where sticky rice functioned as template to control the growth of $\mathrm{CaCO}_{3}$ crystals.

To date, however, research on sticky rice addition in mortars with potential hydraulicity has been relatively scarce $[13,14]$. Therefore, the present study aims to understand some preliminary effects caused by sticky rice addition in hydraulic mortars. To achieve this objective, it was proposed by the current study to first search in historic Chinese accounts to come up with a mortar mix to be executed with a certain grade of plausibility; then prepare lab-specimens which are based on the mortar recipe; finally after experimental study, try to understand the effects caused by the sticky rice addition in the studied mortar. Results of the present study could contribute to the understanding of the material, subsequently shedding light on its innovative use in conservation and repair.

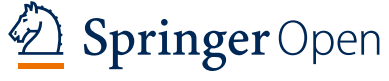

(c) The Author(s) 2021. This article is licensed under a Creative Commons Attribution 4.0 International License, which permits use, sharing adaptation, distribution and reproduction in any medium or format, as long as you give appropriate credit to the original author(s) and the source, provide a link to the Creative Commons licence, and indicate if changes were made. The images or other third party material in this article are included in the article's Creative Commons licence, unless indicated otherwise in a credit line to the material. If material is not included in the article's Creative Commons licence and your intended use is not permitted by statutory regulation or exceeds the permitted use, you will need to obtain permission directly from the copyright holder. To view a copy of this licence, visit http://creativeco mmons.org/licenses/by/4.0/. The Creative Commons Public Domain Dedication waiver (http://creativecommons.org/publicdomain/ zero/1.0/) applies to the data made available in this article, unless otherwise stated in a credit line to the data. 


\section{Mortar recipe for specimen preparation}

Some historic sources [1, 15-17] from Ming (1368-1635 A.D.) and Qing dynasty (1636-1912 A.D.) accounted that adding tile dust to lime would make mortars impervious and strong. Some other literatures $[15,18]$ even suggested adding organic additives such as sticky rice into lime-tile dust mortars. It is generally accepted that fired clay materials such as brick/ tile dust, when formulated with air lime, can react with lime and form calcium silicate hydrates and calcium aluminate hydrates, which could increase mortars' setting speed [19], mechanical strengths [20] and durability [19].

In the current study, the choice of prepared mortar mix compositions and proportions are based on historic accounts, and the reasons for making such choices are listed as follows.

- Inorganic components. A 17 th-century Chinese literature on military defense (武备志 [16]) reported that sand can be excluded from the lime-tile dustsand recipe; for mortars with organic addition, fine tile dust is commonly used. Thus, in the current study, the inorganic components in the mortar specimens were lime and fine tile dust, and sand was excluded to simplify the mortar mix.

- Proportion between lime and tile dust. A historic literature [16] revealed that the hydraulic lime-tile dust recipe was in fact derived from the traditional Chinese tabia (lime-clay) recipe. Clay is of course different from brick/tile dust which are fired materials possessing pozzolanic reactivity. However, the relevant historic accounts on lime-brick/tile dust mortars are scarce, and they do not contain some necessary information for mortar specimen preparation in the present study. Fortunately, the historic Chinese lime-brick/tile dust mortars evolved from lime-clay mortars (tabia), and the accounts on the latter are abundant, which could in turn serve as references for the former. Various proportions of lime: clay can be found in literatures (e.g. 5:3-v/v [5, 21], 14:3-v/v [22], $3: 1-\mathrm{v} / \mathrm{v}$ [4]), yet one of the most famous and commonly adopted recipes was accounted in 天工开物 [23], a renowned 17th-century Chinese encyclopedic work on agriculture, manufacture and industry: "To construct tombs and reservoirs, take 1 part of lime and 2 parts of clay and sand, and knead them with sticky rice porridge or kiwi vine juice." Therefore, in the present study, the chosen ratio between lime and tile dust for lab-prepared mortar specimens was 1:2$\mathrm{v} / \mathrm{v}$.

- Proportion between sticky rice and inorganic components. In historic records, the most frequently accounted sticky rice proportion in masonry mortars was raw sticky rice: lime $=1: 20-v / v$ [3, 24-26], which was adopted in the present study for specimen preparation.

- Proportion between sticky rice and water in sticky rice porridge. Unfortunately, the proportion between sticky rice and water wasn't found in historic literature. However, with the knowledge that the proportion between raw sticky rice grains $\left(\mathrm{V}_{\mathrm{RSR}}\right)$ and lime powder $\left(\mathrm{V}_{\mathrm{L}}\right)$ is $1: 20-\mathrm{v} / \mathrm{v}$ (previous paragraph), such information can be deduced. Considering sticky rice porridge as mixing liquid, the proportion in weight between raw sticky rice $\left(m_{\mathrm{RSR}}\right)$ and water $\left(\mathrm{m}_{\mathrm{W}}\right)$ in porridge can be roughly estimated as $\mathrm{m}_{\mathrm{RSR}} / \mathrm{m}_{\mathrm{W}}=\left(\mathrm{D}_{\mathrm{RSR}} \times \mathrm{V}_{\mathrm{RSR}}\right) /\left(\mathrm{D}_{\mathrm{L}} \times \mathrm{V}_{\mathrm{L}} \times \mathrm{R}_{\mathrm{W} / \mathrm{L}}\right)=\mathrm{D}_{\mathrm{RSR}} /$ $\left(20 \times D_{L} \times R_{W / L}\right)$, where $D_{R S R}$ and $D_{L}$ are respectively the loose bulk density of raw sticky rice grains and lime powder, $\mathrm{R}_{\mathrm{W} / \mathrm{L}}$ is the water/lime ratio needed to achieve a lime paste with appropriate consistency for building operations.

- Temperature of sticky rice porridge. In some literatures [25-27], barrels are included in the construction preparation list for storage of sticky rice porridge, indicating that the porridge could be used at room temperature; while one other literature [21] described that the porridge should be cooked while mixing inorganic mortar components, suggesting that the porridge should be used while still hot. In the current study, mortars with both hot and cold sticky rice porridge addition shall be tested and analyzed to see the possible effect of mixing liquid temperature on such mortars.

To sum up, for the present study, the mortar mix for specimen preparation is composed of hydrated lime, fine tile dust and sticky rice porridge/ water, with ratio of hydrated lime to tile dust of 1:2-v/v, and both hot and cold sticky rice porridge will be added.

\section{Materials and methods \\ Lab-prepared mortar specimens Raw materials}

Analytical-grade calcium hydroxide $\left(\mathrm{Ca}(\mathrm{OH})_{2}, 95.0 \%\right.$, Sinopharm Chemical Reagent), fine tile dust, sticky rice and distilled water were used for specimen preparation. Fine tile dust was purchased from a Chinese lacquerware workshop in Xi'an (China). Sticky rice (Jiulihu Food Co. Ltd.) was purchased from a local supermarket in Xi'an (China). The loose bulk density values (determined according to EN 1097-3: 1998 [28]) of calcium hydroxide powder, fine tile dust powder and sticky rice grains were respectively 500 , 700 and $880 \mathrm{~kg} \mathrm{~m}^{-3}$ at ambient temperature and moisture $\left(\sim 25^{\circ} \mathrm{C}, \sim 50 \% \mathrm{RH}\right)$, which were calculated as the quotient 


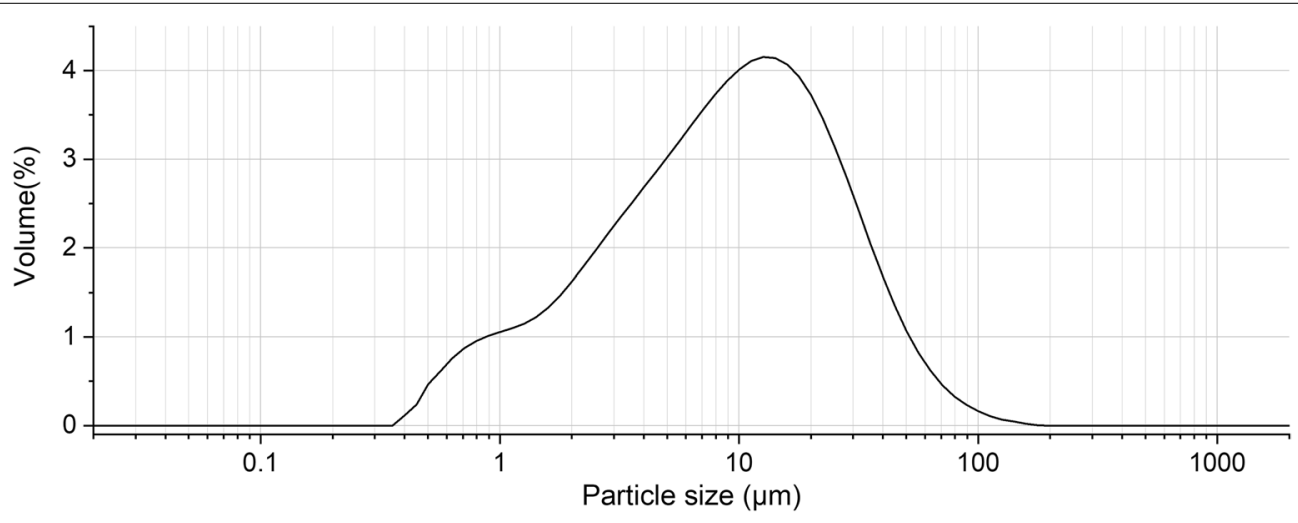

Fig. 1 Particle size distribution of tile dust

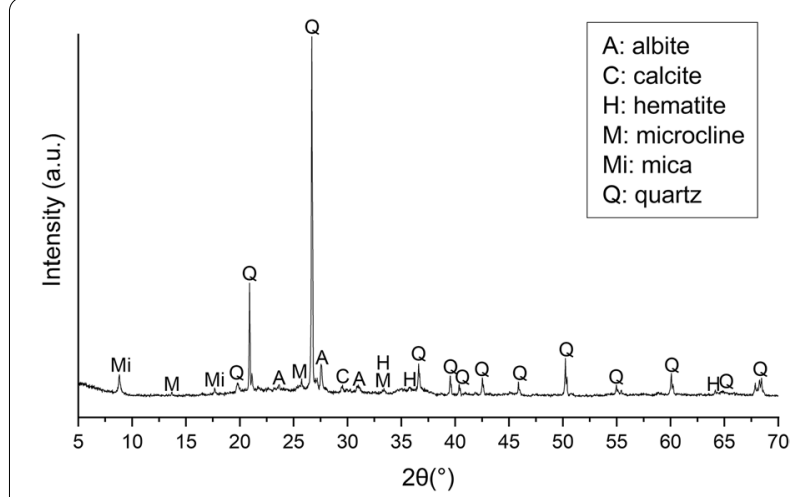

Fig. 2 Mineral compositions of tile dust

of the mass of raw materials filling a graduated cylinder without compaction divided by the capacity of the graduated cylinder.

Particle size distribution of fine tile dust (Fig. 1) was measured by laser diffractometry using Malvern Mastersizer 2000 (Malvern Instruments, U.K.). Particle size of the tile dust was relatively small, with medium grain size (d (0.5)) of $8.6 \mu \mathrm{m}$ and d (0.9) of $30.1 \mu \mathrm{m}$. Mineralogy of fine tile dust was analyzed by a PANalytical X'pert ${ }^{3}$ Powder X-ray diffractometer (PANalytical, Netherlands), and Fig. 2 showed that the characteristic mineral compounds were quartz, feldspars (e.g. albite, microcline), mica, hematite and a small amount of calcite. Elemental composition analysis was carried out with an X-ray fluorescence spectrometer (XRF-1800, Shimadzu, Japan), and Table 1 indicated that the tile dust contains major quantities of $\mathrm{SiO}_{2}$ and $\mathrm{Al}_{2} \mathrm{O}_{3}$, while other components are present in small amounts.

\section{Specimen preparation}

Compositions of lab-prepared mortar specimens were shown in Table 2. As mentioned in "Mortar recipe for specimen preparation" Section, the chosen ratio between lime and tile dust was 1:2 -v/v. Since the loose bulk density values of hydrated lime powder and fine tile dust were 500 and $700 \mathrm{~kg} \mathrm{~m}^{-3}$ ("Raw materials" Section), the lime to tile dust mass ratio was (500*1): $(700 * 2)=1: 2.8-\mathrm{w} / \mathrm{w}$ in the current study.

As mentioned in "Mortar recipe for specimen preparation" Section, the proportion between weight of sticky rice $\left(\mathrm{m}_{\mathrm{RSR}}\right)$ and water $\left(\mathrm{m}_{\mathrm{W}}\right)$ in porridge can be roughly estimated as $\mathrm{m}_{\mathrm{RSR}} / \mathrm{m}_{\mathrm{W}}=\mathrm{D}_{\mathrm{RSR}} /\left(20 \times \mathrm{D}_{\mathrm{L}} \times \mathrm{R}_{\mathrm{W} / \mathrm{L}}\right)$. After several try-outs, the water/ lime ratio was determined at $\sim 0.8-\mathrm{w} / \mathrm{w}$, and knowing the loose bulk density of raw sticky rice grains $\left(880 \mathrm{~kg} / \mathrm{m}^{3}\right)$ and lime powder $\left(500 \mathrm{~kg} \mathrm{~m}^{-3}\right)$ from "Raw materials" Section, $\mathrm{m}_{\mathrm{RSR}} / \mathrm{m}_{\mathrm{W}}=880 /(20 \times 500 \times 0.8)=11$ : $100-\mathrm{w} / \mathrm{w}$. Thus, the sticky rice content in porridge would be $\mathrm{m}_{\mathrm{RSR}} /\left(\mathrm{m}_{\mathrm{W}}+\mathrm{m}_{\mathrm{RSR}}\right)=11 /(11+100)=9.91 \%-\mathrm{w} / \mathrm{w}$, which can be rounded to $10 \%-\mathrm{w} / \mathrm{w}$.

Sticky rice porridge was prepared by first grinding sticky rice grains into fine powder with an electrical pulverizer for $180 \mathrm{~s}$, then mixing the powder with distilled water at 1:9$\mathrm{w} / \mathrm{w}$, and finally cooking the mixture for $4 \mathrm{~h}$ in an electrical cooker. Water was constantly replenished during cooking to keep the original mixture volume, so that the final sticky rice content in the porridge was $10 \%-w / w$. After cooking,

Table 1 Chemical composition of fine tile dust

\begin{tabular}{lccccccccccc}
\hline Chemical composition & $\mathrm{SiO}_{\mathbf{2}}$ & $\mathbf{A l}_{\mathbf{2}} \mathbf{O}_{\mathbf{3}}$ & $\mathrm{Fe}_{\mathbf{2}} \mathbf{O}_{\mathbf{3}}$ & $\mathbf{K}_{\mathbf{2}} \mathbf{O}$ & $\mathbf{M g O}$ & $\mathbf{C a O}$ & $\mathrm{TiO}_{\mathbf{2}}$ & $\mathbf{N a}_{\mathbf{2}} \mathbf{O}$ & $\mathbf{M n O}$ & $\mathbf{P}_{\mathbf{2}} \mathbf{O}_{\mathbf{5}}$ & $\mathbf{S O}_{\mathbf{3}}$ \\
\hline Weight (m\%) & 62.56 & 22.60 & 6.60 & 3.00 & 1.17 & 1.15 & 0.89 & 0.53 & 0.15 & 0.14 & 0.06 \\
\hline
\end{tabular}


Table 2 Information on the composition, dimension and tests/analyses performed on the specimens

\begin{tabular}{|c|c|c|c|}
\hline Specimen & Composition & Specimen dimension & Tests/analyses performed \\
\hline L-TD-W-50\% & hydrated lime: tile dust: distilled water $=1: 2.8: 1.8-\mathrm{w} / \mathrm{w}$ & $\begin{array}{l}\Phi 6^{*} 1.5 \mathrm{~cm}^{3} \\
5 * 5 * 5 \mathrm{~cm}^{3}\end{array}$ & $\begin{array}{l}\text { FTIR, XRD, TG-DSC } \\
\text { bulk density, compressive strength, water absorption }\end{array}$ \\
\hline L-TD-HSR-50\% & $\begin{array}{l}\text { hydrated lime: tile dust: hot sticky rice porridge }=1: 2.8 \text { : } \\
2-w / w\end{array}$ & $\begin{array}{l}\Phi 6 * 1.5 \mathrm{~cm}^{3} \\
5 * 5 * 5 \mathrm{~cm}^{3}\end{array}$ & $\begin{array}{l}\text { FTIR, XRD, TG-DSC } \\
\text { bulk density, compressive strength, water absorption }\end{array}$ \\
\hline L-TD-CSR-50\% & $\begin{array}{l}\text { hydrated lime: tile dust: cold sticky rice porridge }=1 \text { : } \\
\text { 2.8: } 2-w / w\end{array}$ & $\begin{array}{l}\Phi 6 * 1.5 \mathrm{~cm}^{3} \\
5 * 5 * 5 \mathrm{~cm}^{3}\end{array}$ & $\begin{array}{l}\text { FTIR, XRD, TG-DSC } \\
\text { bulk density, compressive strength, water absorption }\end{array}$ \\
\hline L-TD-W-95\% & hydrated lime: tile dust: distilled water $=1: 2.8: 1.8-\mathrm{w} / \mathrm{w}$ & $\begin{array}{l}\Phi 6 * 1.5 \mathrm{~cm}^{3} \\
5 * 5 * 5 \mathrm{~cm}^{3}\end{array}$ & $\begin{array}{l}\text { FTIR, XRD, TG-DSC } \\
\text { bulk density, compressive strength, water absorption }\end{array}$ \\
\hline L-TD-HSR-95\% & $\begin{array}{l}\text { hydrated lime: tile dust: hot sticky rice porridge }=1: 2.8 \text { : } \\
2-w / w\end{array}$ & $\begin{array}{l}\Phi 6 * 1.5 \mathrm{~cm}^{3} \\
5 * 5 * 5 \mathrm{~cm}^{3}\end{array}$ & $\begin{array}{l}\text { FTIR, XRD, TG-DSC } \\
\text { bulk density, compressive strength, water absorption }\end{array}$ \\
\hline L-TD-CSR-95\% & $\begin{array}{l}\text { hydrated lime: tile dust: cold sticky rice porridge }=1 \text { : } \\
\text { 2.8: } 2-w / w\end{array}$ & $\begin{array}{l}\Phi 6^{*} 1.5 \mathrm{~cm}^{3} \\
5 * 5 * 5 \mathrm{~cm}^{3}\end{array}$ & $\begin{array}{l}\text { FTIR, XRD, TG-DSC } \\
\text { bulk density, compressive strength, water absorption }\end{array}$ \\
\hline L-W-50\% & hydrated lime: distilled water = 1: $1.8-\mathrm{w} / \mathrm{w}$ & $\Phi 6^{*} 1.5 \mathrm{~cm}^{3}$ & FTIR, XRD, TG-DSC \\
\hline L-HSR-50\% & hydrated lime: hot sticky rice porridge $=1: 2-\mathrm{w} / \mathrm{w}$ & $\Phi 6^{*} 1.5 \mathrm{~cm}^{3}$ & FTIR, XRD, TG-DSC \\
\hline L-CSR-50\% & hydrated lime: cold sticky rice porridge $=1: 2-\mathrm{w} / \mathrm{w}$ & $\Phi 6^{*} 1.5 \mathrm{~cm}^{3}$ & FTIR, XRD, TG-DSC \\
\hline
\end{tabular}

sticky rice porridge was added in mortars at both "cold" and "hot" temperatures: half of the porridge was taken out and brought to room temperature $\left(\sim 25^{\circ} \mathrm{C}\right)$, designated as "cold sticky rice (CSR)"; the other half was left in the cooker while keeping the temperature at $\sim 80{ }^{\circ} \mathrm{C}$, designated as "hot sticky rice (HSR)".

Mortar mixes were prepared by first mixing the inorganic components, then continuing mixing while adding distilled water (at room temperature) or sticky rice porridge. Water or sticky rice porridge was added according to personal experience so that the mortar would fit the workability features generally required in building operations. Additionally, it was also intended that the same water amount is present in each mortar mix. To be more specific, in Table 2 the proportions among the components of L-TD-W are hydrated lime: tile dust: distilled water $=1: 2.8: 1.8-\mathrm{w} / \mathrm{w}$, and those of L-TD-HSR/CSR are hydrated lime: tile dust: sticky rice porridge $=1: 2.8: 2-\mathrm{w} / \mathrm{w}$. Since the water content in sticky rice porridge is $90 \%-\mathrm{w} / \mathrm{w}$ (as mentioned in previous paragraph), the theoretical water amount in L-TDHSR/CSR is the same as L-TD-W. For FTIR, XRD and TG-DSC analyses, mortar mixes without tile dust were also prepared-while keeping the original proportions of hydrated lime to water $(1: 1.8-\mathrm{w} / \mathrm{w})$ or sticky rice (1: 2 -w/w) - intending to further evidence the effects of sticky rice on hydrated lime.

Specimens were prepared in two dimensions: $5 * 5 * 5 \mathrm{~cm}^{3}$ cubes for hardened mortar density, water absorption and compressive strength tests, and $\Phi 6 * 1.5 \mathrm{~cm}^{3}$ discs for FTIR, XRD and TG-DSC analyses. Specimens were stored under both dry $\left(\sim 25{ }^{\circ} \mathrm{C}, \sim 50 \% \mathrm{RH}\right)$ and humid $\left(\sim 25^{\circ} \mathrm{C}, \sim 95 \% \mathrm{RH}\right)$ conditions for 180 days.

\section{Methods \\ Property tests}

Table 3 shows the property tests conducted on fresh and hardened mortars, and the number of specimens tested.

Table 3 Property tests conducted on fresh and hardened mortars, and the number of specimens tested

\begin{tabular}{|c|c|c|c|c|c|c|c|}
\hline & Property test & & L-TD-W & & L-TD-HSR & & L-TD-CSR \\
\hline \multirow[t]{4}{*}{ Fresh mortar } & Water retention & & 2 & & 2 & & 2 \\
\hline & Setting time & & 1 & & 1 & & 1 \\
\hline & Bulk density & & 2 & & 2 & & 2 \\
\hline & Property test & L-TD-W-50\% & $\begin{array}{l}\text { L-TD- } \\
\text { HSR-50\% }\end{array}$ & $\begin{array}{l}\text { L-TD- } \\
\text { CSR- } 50 \%\end{array}$ & L-TD-W-95\% & $\begin{array}{l}\text { L-TD- } \\
\text { HSR-95\% }\end{array}$ & $\begin{array}{l}\text { L-TD- } \\
\text { CSR-95\% }\end{array}$ \\
\hline \multirow[t]{2}{*}{ Hardened mortar } & $\begin{array}{l}\text { Bulk density ( } 28 \mathrm{~d} \text { ) } \\
\text { Water absorption ( } 60 \mathrm{~d}) \\
\text { Compressive strength (60 d) }\end{array}$ & 3 & 3 & 3 & 3 & 3 & 3 \\
\hline & $\begin{array}{l}\text { Water absorption (180 d) } \\
\text { Compressive strength (180 d) }\end{array}$ & 3 & 3 & 3 & 3 & 3 & 3 \\
\hline
\end{tabular}


Water retention test was conducted according to Chinese standard JGJ/T70-2009 [29]. Freshly-mixed mortar was poured into a metal ring $\left(\Phi 100 * 25 \mathrm{~mm}^{3}\right)$, then quickly came in contact with filter papers for $2 \mathrm{~min}$, pressed upon by a lead cube weighing $2 \mathrm{~kg}$ to simulate the suction from porous substrates. Water retention capacity of the mortar mix was characterized by the mass of water it retained after filter paper absorption. Then, knowing the water content of the tested mortar (Table 2), water retention was calculated by: $\mathrm{WR}=\left[1-\mathrm{m}_{2} / \mathrm{m}_{1}\right] \times 100 \%$, where $m_{2}$ is the quantity of water retained by the filter paper, $m_{1}$ is the quantity inside the studied mortar. For each mortar mix, two samples were used for water retention test, and the mean value and standard deviation of the two samples was reported.

Setting time was determined by Vicat apparatus according to BS EN 480-2: 2006 [30], which observes the rate of mortar hardening by dropping a needle from a fixed height and measuring its penetration into the mortar. Initial setting time was determined as the time measured from completion of mixing until the time at which the distance between the needle and the base-plate was $(4 \pm 1) \mathrm{mm}$. Final setting time was determined as the time measured from completion of mixing until the time after which the needle no longer penetrates $0.5 \mathrm{~mm}$ into the specimen. One sample from each mortar mix was used for setting time test.

Bulk density values of fresh and hardened mortar were respectively determined according to European standards BS EN 1015-6: 1999 [31] and BS EN 1015-10: 1999 [32], by the quotient of its mass and the volume which it occupies. For each mortar mix, two fresh mortar samples were used for fresh mortar bulk density test, and the mean value and standard deviation of the two samples was reported. For each mortar mix, three hardened mortar specimens were used for hardened mortar bulk density test, and the mean value and standard deviation of the three specimens was reported.

Compressive strength test was conducted on the $5 \mathrm{~cm}$ test cubes according to Chinese standard JGJ/T70-2009 [29], after 60 and 180 days of curing by a WDW-20 electronic universal testing machine (Zhongluchang Manufacturing Co., Ltd, China) at $0.2 \mathrm{kN} / \mathrm{s}$ loading rate. For each mortar mix, three mortar specimens were used for the test, and the mean value and standard deviation of the three specimens was reported.

Water absorption test was conducted on $5 \mathrm{~cm}$ test cubes after 60 and 180 days of curing according to Chinese standard JGJ/T70-2009 [29]. Before test, the specimen cubes were dried in oven at $80{ }^{\circ} \mathrm{C}$ to constant mass to fully evaporate the water present in mortars. When taken out and cooled to room temperature, with the top surface facing down, they were placed in a flat-bottom container, supported by two steel rods $(\Phi 10 \mathrm{~mm})$, and partially immersed in $35 \mathrm{~mm}$-deep distilled water under $\sim 25{ }^{\circ} \mathrm{C}$ and $\sim 95 \% \mathrm{RH}$. The weight of each specimen was measured by an electrical balance (accuracy $0.01 \mathrm{~g})$ at $1,3,5,10,15,20,25,30,40,50,60 \mathrm{~min}$, and $2,3,4,5,6,24,36$ and $48 \mathrm{~h}$ after immersion. It was suggested by the standard that the water absorption $(\mathrm{m} \%)$ should be calculated as $\mathrm{W}=\left(\mathrm{m}_{1}-\mathrm{m}_{0}\right) / \mathrm{m}_{0}$, where $\mathrm{m}_{0}$ and $\mathrm{m}_{1}$ are masses before and after absorption, respectively. However, the authors decided to report water absorption values as water absorption $\left(\mathrm{g} \mathrm{m}^{-2}\right)$ vs time ${ }^{1 / 2}\left(\mathrm{~s}^{1 / 2}\right)$ so that the data can better represent the permeability of mortars. Water absorption coefficient values were calculated according to standard BS EN 1925: 1999 [33]. The calculation principle was that the plotted specimen graphs can be approximated by two straight lines, and the coefficient of water absorption by capillarity can be represented by the slope of the regression line of the first part (the increasing part) of the graph. For each mortar mix, three mortar specimens were used for the test, and the mean value and standard deviation of water absorption and water absorption coefficient of the three specimens were reported.

\section{Analyses}

Fourier transform infrared spectroscopy (FTIR), X-ray diffraction analysis (XRD) and thermogravimetry and differential scanning calorimetry (TG-DSC) were performed on specimens after 60 and 180 days of curing. Before analysis, all specimens were vacuum-dried in oven for $48 \mathrm{~h}$ at $60^{\circ} \mathrm{C}$ to evaporate excess water in mortar pores and capillaries.

FTIR in transmission mode was performed using a Thermo Fisher Scientific Nicolet iS50 Spectrometer (Thermo Fischer Scientific Inc., U.S.A.). The samples were ground into fine powder and subsequently analyzed as $\mathrm{KBr}$ pellets (wavenumber $4000-400 \mathrm{~cm}^{-1}$, resolution $4 \mathrm{~cm}^{-1}, 64$ scans).

XRD was conducted using a PANalytical X'pert ${ }^{3}$ Powder X-ray diffractometer (PANalytical, Netherlands), with $\mathrm{Cu}-\mathrm{K} \alpha$ radiation $(\lambda=1.540598 \AA), 2 \theta$ range $5-90^{\circ}$, step scan $0.01^{\circ}$, scan speed $10^{\circ} \mathrm{min}^{-1}$, at $40 \mathrm{kV}$ and $100 \mathrm{~mA}$.

TG-DSC was performed by means of a Mettler Toledo TGA/DSC1 instrument (Mettler Toledo, Switzerland). Samples were placed in aluminum crucibles, with temperature ranging from room temperature to $1000{ }^{\circ} \mathrm{C}$ under pure $\mathrm{N}_{2}$ atmosphere, heating rate at $10{ }^{\circ} \mathrm{C} \mathrm{min}^{-1}$.

\section{Results and discussion}

Water retention, setting time and bulk density

Table 4 showed that lime-tile dust mortars with sticky rice addition had higher water retention values than 
Table 4 Water retention, setting time and bulk density of mortar mixes and specimens

\begin{tabular}{|c|c|c|c|c|c|}
\hline & & & L-TD-W & L-TD-HSR & L-TD-CSR \\
\hline Water retention (m\%) & & & $93.7 \pm 0.2$ & $99.7 \pm 0.1$ & $99.5 \pm 0.1$ \\
\hline \multirow[t]{2}{*}{ Setting time } & Initial (h) & & 4.33 & 5.83 & 6.33 \\
\hline & Final (h) & & 28.50 & 38.67 & 39.17 \\
\hline \multirow[t]{3}{*}{ Bulk density $\left(\mathrm{kg} / \mathrm{m}^{3}\right)$} & Fresh mortar & & $1270 \pm 80$ & $1010 \pm 60$ & $1000 \pm 80$ \\
\hline & $28 \mathrm{~d}$ hardened mortar & $50 \% \mathrm{RH}$ & $860 \pm 50$ & $720 \pm 40$ & $710 \pm 40$ \\
\hline & & $95 \% \mathrm{RH}$ & $1230 \pm 90$ & $950 \pm 60$ & $950 \pm 50$ \\
\hline
\end{tabular}

those without. Sticky rice porridge which is comprised of water and starch as gelling agent, could be regarded as an aquagel [34]. When homogeneously incorporated into mortar mixes, a large portion of the water in sticky rice porridge was physically bound and could not easily leakoff into a porous substrate [35].

Sticky rice porridge increased both initial and final setting time of the studied lime-tile dust mortar. The prolongation effect of saccharide additives on the setting time of cement mortars was well-known, which might be linked to adsorption of admixtures onto surfaces of the hydrated and/or anhydrous phases [36, 37] through the complexation of saccharides and their alkaline degradation products [38] with metal ions such as $\mathrm{Ca}^{2+}[39,40]$, forming semipermeable coating and delaying the formation of hydration products [41].

Addition of sticky rice porridge into lime-tile dust mortars decreased both fresh and hardened bulk density values under both dry and humid curing. As mentioned earlier, sticky rice porridge can be considered as an aquagel. When homogeneously incorporated into fresh mortar mixes, it became encased within the mortar. As mortar dried, the aquagel shrank, and void spaces were developed. Moisture from within the aquagel particles slowly diffused to the surface of the mortar and evaporated, further reducing mortar density. [34, 42]

\section{Water absorption}

After curing for 60 days (Fig. 3a), at $48 \mathrm{~h}$ after immersion, specimens with sticky rice cured under both dry and humid conditions achieved similarly high absorption values (averaged at 24,080-24,840 $\mathrm{g} \mathrm{m}^{-2}$, Table 5). Meanwhile, specimens without sticky rice had the lowest water absorption values (averaged 22,000 $\mathrm{g} \mathrm{m}^{-2}$ for L-TD-W-50\% and 20,400 $\mathrm{g} \mathrm{m}^{-2}$ for L-TD-W-95\%), demonstrating increased water absorption with sticky rice addition, which was also reported in Zhao et al.[9]. Such increase of water absorption should be due to more pore volume in mortars with sticky rice addition, which was resulted from the void spaces formed after sticky rice porridge dried and shrank (discussed in "Water absorption" Section).
After 180 days of curing, the absorption values of specimens cured under 50\% RH basically didn't change (Table 5), yet the values of those cured under 95\% RH declined (Fig. $3 \mathrm{~b}$ and Table 5). The average absorption values of L-TD-W-95\%, L-TD-HSR-95\% and L-TDCSR-95\% after $48 \mathrm{~h}$ water immersion respectively reached 12,800, 20,400 and 20,200 $\mathrm{kg} \mathrm{m}^{-2}$, decreasing the average values by $37.3,17.5$ and $18.7 \%$ compared to the data measured after 60 days of curing. Additionally, humid curing reduced water absorption coefficient values of specimens cured for both 60 and 180 days (Table 5). Reduced water absorption and water absorption coefficient values could indicate diminished pore size, volume and/or capillary interconnections, which should be due to the continuous formation of hydration products under humid curing condition, taking up more space in mortar pores, making mortar denser and more compact.

\section{Compressive strength}

Figure 4 showed that under $50 \% \mathrm{RH}$ curing, mortars without sticky rice addition achieved the highest compressive strength values after 60 and 180 days of curing $(0.97 \pm 0.08$ and $2.08 \pm 0.18 \mathrm{MPa})$, while L-TD-HSR- $50 \%$ $(0.41 \pm 0.03$ and $0.79 \pm 0.02 \mathrm{MPa})$ and L-TD-CSR-50\% $(0.44 \pm 0.01$ and $0.81 \pm 0.08 \mathrm{MPa})$ had similarly lower values. Such results are in accord with the lower $28 \mathrm{~d}$ hardened mortar density values of L-TD-HSR-50\% and L-TD-CSR-50\% (Table 4), since lighter material would result in weaker structures, thereby decreasing mortar strengths. Additionally, Yang et al. [43] also reported decreasing compressive strength in hydraulic lime mortars (lime- slag, lime- fly ash, lime- silicon fume) with increasing sticky rice content in mortars, which could indicate an inhibiting effect of polysaccharides and proteins on the pozzolanic reaction of such specimens.

The 60 and $180 \mathrm{~d}$ compressive strength values of L-TD-W-95\% (4.27 \pm 0.38 and $6.49 \pm 0.41 \mathrm{MPa})$ were much higher than those of L-TD-W-50\% (0.97 \pm 0.08 and $2.08 \pm 0.18 \mathrm{MPa}$ ), due to the enhanced pozzolanic reactions under higher relative humidity [44, 45]. The strength values of L-TD-HSR-95\% $\quad(0.80 \pm 0.06$ and $1.85 \pm 0.15 \mathrm{MPa})$ and L-TD-CSR-95\% (0.62 \pm 0.03 and 


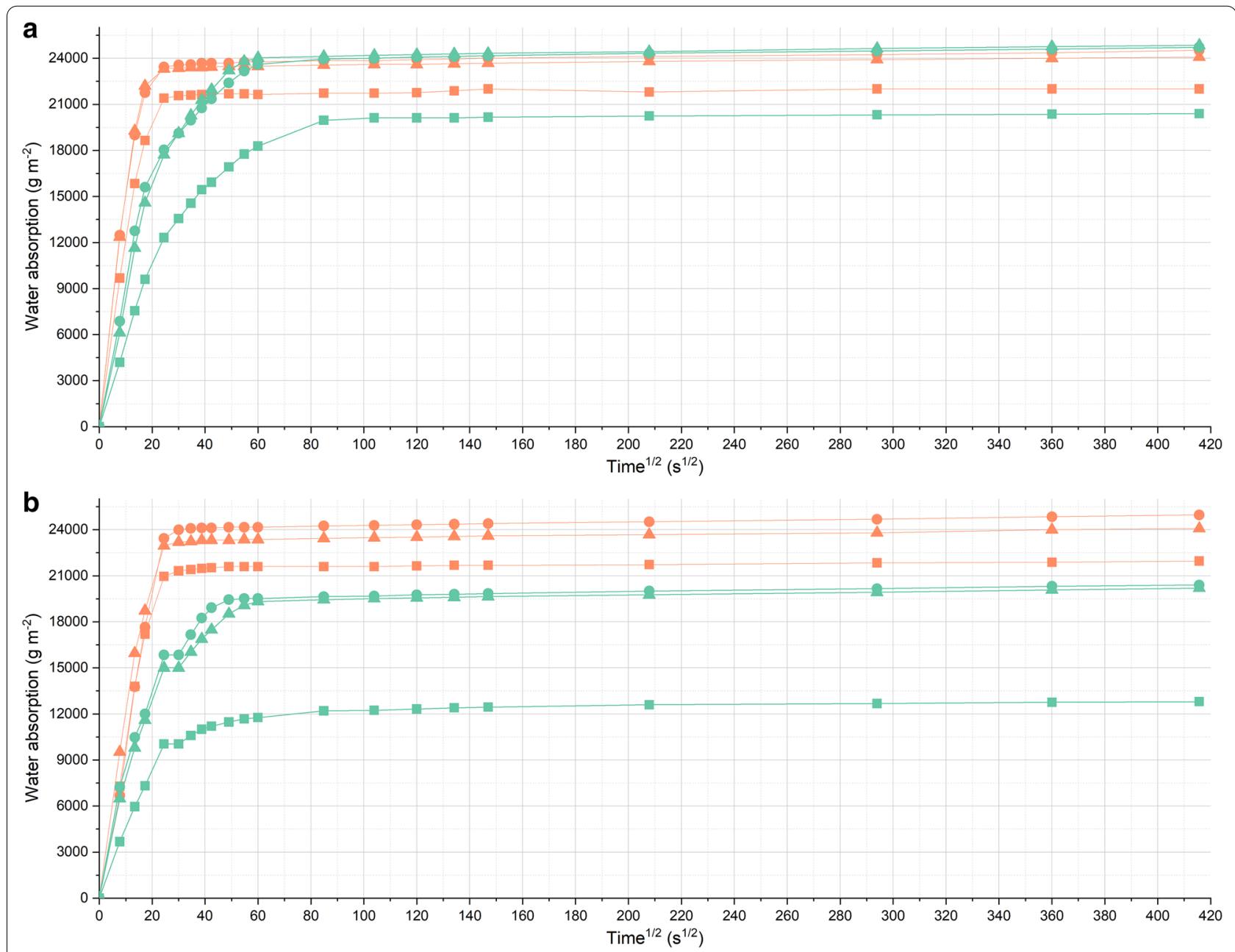

Fig. 3 Water absorption of specimens after $\mathbf{a} 60$ and $\mathbf{b} 180$ days of curing

Table 5 Water absorption and water absorption coefficient values of specimens after 60 and 180 days of curing

\begin{tabular}{|c|c|c|c|}
\hline Curing time when tested & Specimen & $\begin{array}{l}\text { Water absorption at } 48 \mathrm{~h} \\
\text { after immersion }\left(\mathrm{g} \mathrm{m}^{-2}\right)\end{array}$ & $\begin{array}{l}\text { Water absorption } \\
\text { coefficient }\left(\mathrm{g} \mathrm{m}^{-2} \mathrm{~s}^{-1 / 2}\right)\end{array}$ \\
\hline \multirow[t]{6}{*}{$60 d$} & L-TD-W-50\% & $22,000 \pm 880$ & $1045 \pm 53$ \\
\hline & L-TD-HSR-50\% & $24,520 \pm 1070$ & $1312 \pm 37$ \\
\hline & L-TD-CSR-50\% & $24,080 \pm 1230$ & $1275 \pm 29$ \\
\hline & L-TD-W-95\% & $20,400 \pm 930$ & $569 \pm 28$ \\
\hline & L-TD-HSR-95\% & $24,720 \pm 810$ & $880 \pm 33$ \\
\hline & L-TD-CSR-95\% & $24,840 \pm 1140$ & $864 \pm 24$ \\
\hline \multirow[t]{6}{*}{$180 d$} & L-TD-W-50\% & $21,960 \pm 720$ & $1018 \pm 32$ \\
\hline & L-TD-HSR-50\% & $24,960 \pm 930$ & $1054 \pm 22$ \\
\hline & L-TD-CSR-50\% & $24,080 \pm 860$ & $1134 \pm 55$ \\
\hline & L-TD-W-95\% & $12,800 \pm 490$ & $408 \pm 25$ \\
\hline & L-TD-HSR-95\% & $20,400 \pm 820$ & $685 \pm 36$ \\
\hline & L-TD-CSR-95\% & $20,200 \pm 700$ & $654 \pm 29$ \\
\hline
\end{tabular}




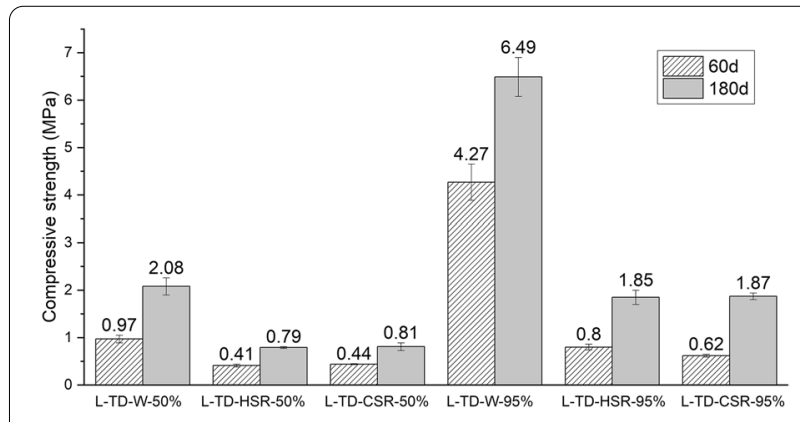

Fig. 4 Compressive strength values of the specimens after 60 and 180 days (d) of curing
$1.87 \pm 0.07 \mathrm{MPa}$ ) were significantly lower than those of L-TD-W-95\%, demonstrating that the strong retarding effect of sticky rice addition on mortar hydration could last for months, as also shown in [46]. Meanwhile, all specimens cured under 95\% RH for 180 days had higher compressive strength values than those cured for 60 days, corroborating the water absorption test results ("Water absorption" Section) that water absorption and water absorption coefficient values were reduced after 180 days of curing.

\section{FTIR}

According to Fig. 5a and Table 6, for all specimens cured under $50 \% \mathrm{RH}$, the relative intensity of the
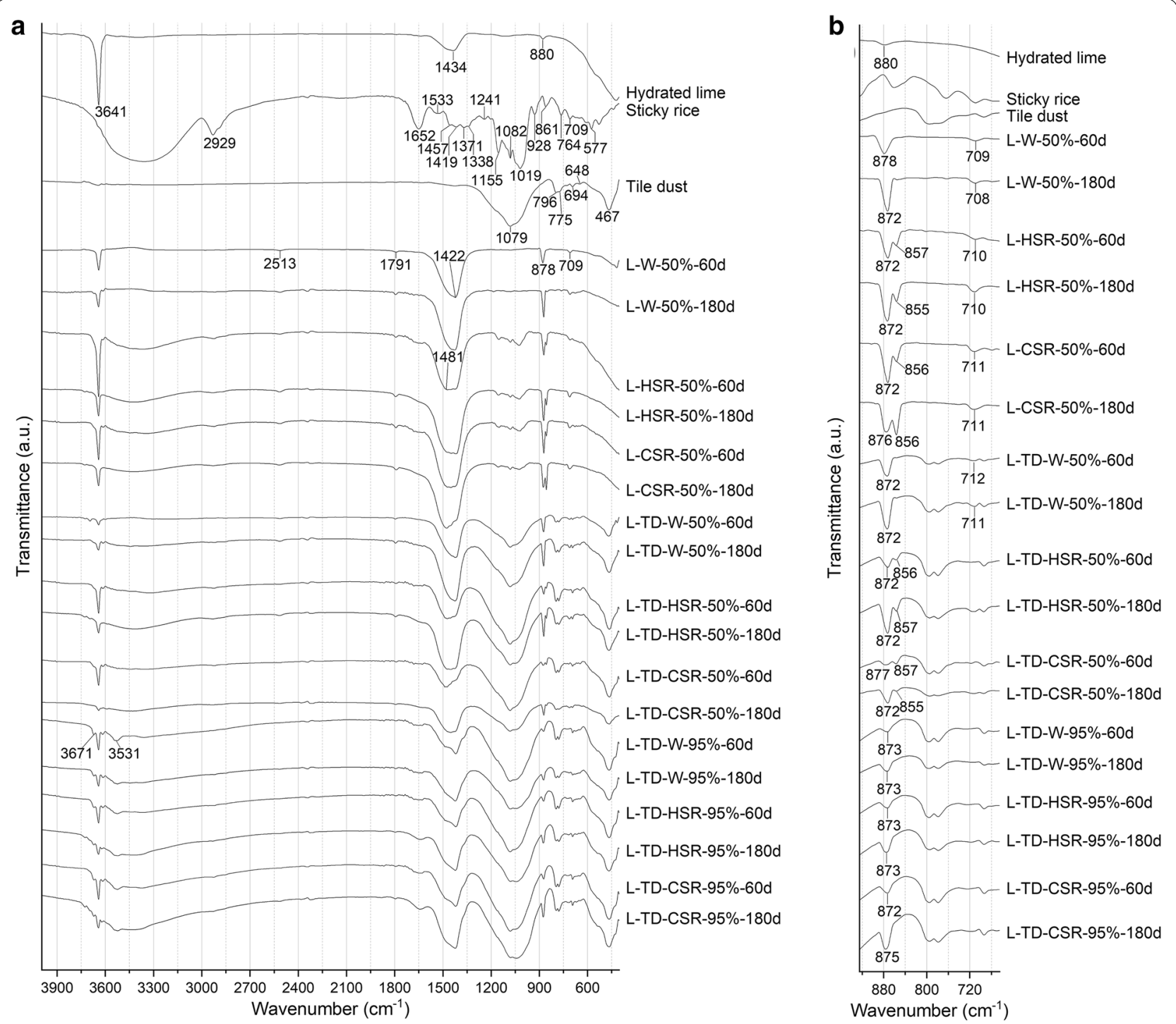

Fig. 5 FTIR spectra (a wavenumber $4000-400 \mathrm{~cm}^{-1}$; b wavenumber $920-660 \mathrm{~cm}^{-1}$ ) of raw materials and specimens cured for 60 and 180 days (d) 
Table 6 FTIR band assignment of calcite, tile dust and sticky rice powder

\begin{tabular}{|c|c|c|}
\hline & Wavenumber $\left(\mathrm{cm}^{-1}\right)$ & Band assignment \\
\hline \multirow[t]{5}{*}{ Calcite } & $\sim 2513$ & $\begin{array}{l}\mathrm{v} 1\left(\mathrm{CO}_{3}{ }^{2-} \text { symmetric stretching) }+\mathrm{v} 3\left(\mathrm{CO}_{3}{ }^{2-} \text { asymmetric stretching) and/or } 2 \mathrm{v} 2 \text { (O-C-O out-of-plane }\right.\right. \\
\text { bending) }+\mathrm{v} 4 \text { ( } \mathrm{C}-\mathrm{O} \text { in-plane bending }[47]\end{array}$ \\
\hline & $\sim 1791$ & $v 1+v 4[47,48]$ \\
\hline & $\sim 1422$ & v3 [48] \\
\hline & $\sim 878$ & V2 [48] \\
\hline & $\sim 709$ & v4 [48] \\
\hline \multirow[t]{5}{*}{ Tile dust } & $\sim 1079$ & Asymmetric si-o stretching $[49,50]$ \\
\hline & $\sim 796$ and 775 & Symmetric si-o stretching $[50,51]$ \\
\hline & $\sim 694$ & Si-O symmetric bending [50] \\
\hline & $\sim 648$ & Tetrahedral ring vibration [52] \\
\hline & $\sim 467$ & Si-O-Si bending $[49,50]$ \\
\hline \multirow[t]{17}{*}{ Sticky rice } & $\sim 3700-3000$ & O-H stretching of carboxylic acids and polysaccharides [53-55] \\
\hline & $\sim 2929$ & Aliphatic $\mathrm{C}-\mathrm{H}$ stretching in $\mathrm{CH}_{2}$ and $\mathrm{CH}_{3}$ groups of carboxylic acids and esters in polysaccharides [53-55] \\
\hline & $\sim 1652$ & $\begin{array}{l}\text { Asymmetric -COO stretching }[55] \\
\mathrm{C}=\mathrm{O} \text { symmetric stretching (amide I) }[53,54] \\
\text { Water molecules absorbed in the amorphous region }[56]\end{array}$ \\
\hline & $\sim 1533$ & $\mathrm{~N}-\mathrm{H}$ in-plane bending vibration strongly coupled to $\mathrm{C}-\mathrm{N}$ stretching vibration of protein (amide II) $[53,57]$ \\
\hline & $\sim 1457$ & $\mathrm{CH}_{2}$ group scissoring modes [53] \\
\hline & $\sim 1419$ & $-\mathrm{CH}_{2}$ bending and symmetric $-\mathrm{COO}$ stretch $[55,58]$ \\
\hline & $\sim 1371$ & $\mathrm{CH}$ deformation or $\mathrm{CH}_{2}$ vibration [59] \\
\hline & $\sim 1338$ & $-\mathrm{CCH}$ and $-\mathrm{OCH}$ coupled bend $\mathrm{CH}_{2}$ rocking vibration [59] \\
\hline & $\sim 1241$ & $\mathrm{CH}_{2} \mathrm{OH}$ (side chain) related mode [59] \\
\hline & $\sim 1155$ & Vibrations of the glucosidic $\mathrm{C}-\mathrm{O}-\mathrm{C}$ bond and the whole glucose ring [58] \\
\hline & $\sim 1082$ & $\begin{array}{l}\mathrm{C}-\mathrm{O}-\mathrm{H} \text { bend vibration }[59] \\
\text { Crystalline regions of starch [58] }\end{array}$ \\
\hline & $\sim 1019$ & Amorphous regions of starch [58] \\
\hline & $\sim 928$ & Skeletal mode vibrations of $\mathrm{a}(1 \rightarrow 4)$ skeletal glycosidic linkage $[58,59]$ \\
\hline & $\sim 861$ & $\mathrm{C}(1) \mathrm{H}, \mathrm{CH}_{2}$ deformation vibration [59] \\
\hline & $\sim 764$ & C-C stretch [60] \\
\hline & $\sim 709$ & Skeletal modes [59] \\
\hline & $\sim 577$ & Skeletal modes of the pyranose ring [58] \\
\hline
\end{tabular}

absorption band at $\sim 3641 \mathrm{~cm}^{-1}$ (free $\mathrm{O}-\mathrm{H}$ stretching from portlandite) is higher in the specimens with sticky rice (L-HSR/CSR-50\%, L-TD-HSR/CSR-50\%) than those without (L-W-50\%, L-TD-W-50\%), suggesting less portlandite consumption induced by the sticky rice addition. Meanwhile, in L-W-50\% and L-TD-W-50\%, all main calcite bands are present, centered at $\sim 2513, \sim 1789, \sim 1421, \sim 875$ and $\sim 710 \mathrm{~cm}^{-1}$ [47, 48, 61, 62]. In L-TD-W-95\% and L-TD-HSR/CSR$95 \%$, although the bands at $\sim 1421$ and $\sim 875 \mathrm{~cm}^{-1}$ are present in their spectra, the intensity of $\sim 710 \mathrm{~cm}^{-1}$ band remained relatively low throughout 180 days of curing, which should be due to less calcite formation under high relative humidity. For specimens with sticky rice cured under dry condition (L-HSR/ CSR-50\%, L-TD-HSR/CSR-50\%), the intensity of $\sim 710 \mathrm{~cm}^{-1}$ band was also low (Fig. $5 \mathrm{~b}$ ), which indicates the absence of significant amounts of crystalline calcium carbonate [63]. Hydroxyl and carboxyl functional groups present in sticky rice and its alkaline degradation byproducts could adsorb onto positively charged $\mathrm{Ca}(\mathrm{OH})_{2}$ faces [55], inhibiting nucleation and limiting the crystallization of calcium carbonate.

Apart from calcite bands, the spectra of specimens with sticky rice cured under 50\% RH (L-HSR/CSR-50\%, L-TD-HSR/CSR-50\%) also showed bands at 1481 (v3) (Fig. 5a) and $\sim 857$ ( $v 2$ ) (Fig. 5b), which indicates the presence of aragonite. The formation of aragonite in air lime mortars with sticky rice and other polysaccharidebased additives such as cactus was also reported in other studies $[64,65]$. The possible mechanism could be: i) lowering of nucleation barrier relative to calcite; ii) stabilization of aragonite through interference with aragonite to calcite transformation pathways; iii) slight cessation of calcite stabilization [66]. In mortars with hot sticky rice porridge addition, relatively high 
temperature $\left(58{ }^{\circ} \mathrm{C}\right)$ and appropriate $\mathrm{pH}$ values $(\sim 11)$ could also facilitate aragonite formation [67].

For all specimens cured under humid condition, the band at $3671 \mathrm{~cm}^{-1}$ could be attributed to hydrogarnet $\left(\mathrm{C}_{3} \mathrm{AH}_{6}\right)$, while the band sited at $3531 \mathrm{~cm}^{-1}$ could be due to gibbsite $\left(\mathrm{AH}_{3}\right)$ [68] (Fig. 5a), which were both more stable cubic forms converted from the metastable phases in the $\mathrm{CaO}-\mathrm{Al}_{2} \mathrm{O}_{3}-\mathrm{H}_{2} \mathrm{O}$ system [69].

\section{XRD}

The presence of calcite in the specimens was evidenced by the main peak at $2 \theta \approx 29.4^{\circ}$ [70], whose intensity was higher in specimens L-W-50\% and L-TD-W-50\% (Fig. 6), confirming FTIR results ("FTIR" Section). In L-HSR-50\% and L-CSR-50\%, some low intensity aragonite peaks can be noted (e.g., $2 \theta \approx 26.3^{\circ}$ and $27.2^{\circ}$ ), while in hydraulic mortars with sticky rice addition (L-TD-HSR/CSR-50\%,
L-TD-HSR/CSR-95\%) these peaks were overlapped by the quartz and feldspar peaks from the raw material tile dust. However, FTIR results (Fig. 5b) could validate the presence of aragonite together with calcite in these specimens.

All specimens cured under 95\% RH showed peaks at $2 \theta \approx 11.7^{\circ}$ and $23.4^{\circ}$, indicating presence of tetracalcium aluminate hydrate $\left(\mathrm{C}_{4} \mathrm{AH}_{13}\right.$ [71]) and monocarboaluminate $\left(\mathrm{C}_{3} \mathrm{ACcH}_{11}\right.$ [72]. These products were formed as a result of reactions between reactive aluminates in metakaolin (or as in this case from pozzolanic tile dust) and $\mathrm{CO}_{3}{ }^{2-}$ ions in mortar mix [73]), which were both reported to be capable of providing strength in concrete $[74,75]$, and concords with the results of compressive strength test ("Compressive strength" Section) that specimens cured under 95\% RH achieved higher compressive strength values than their counterparts cured under $50 \%$ $\mathrm{RH}$.

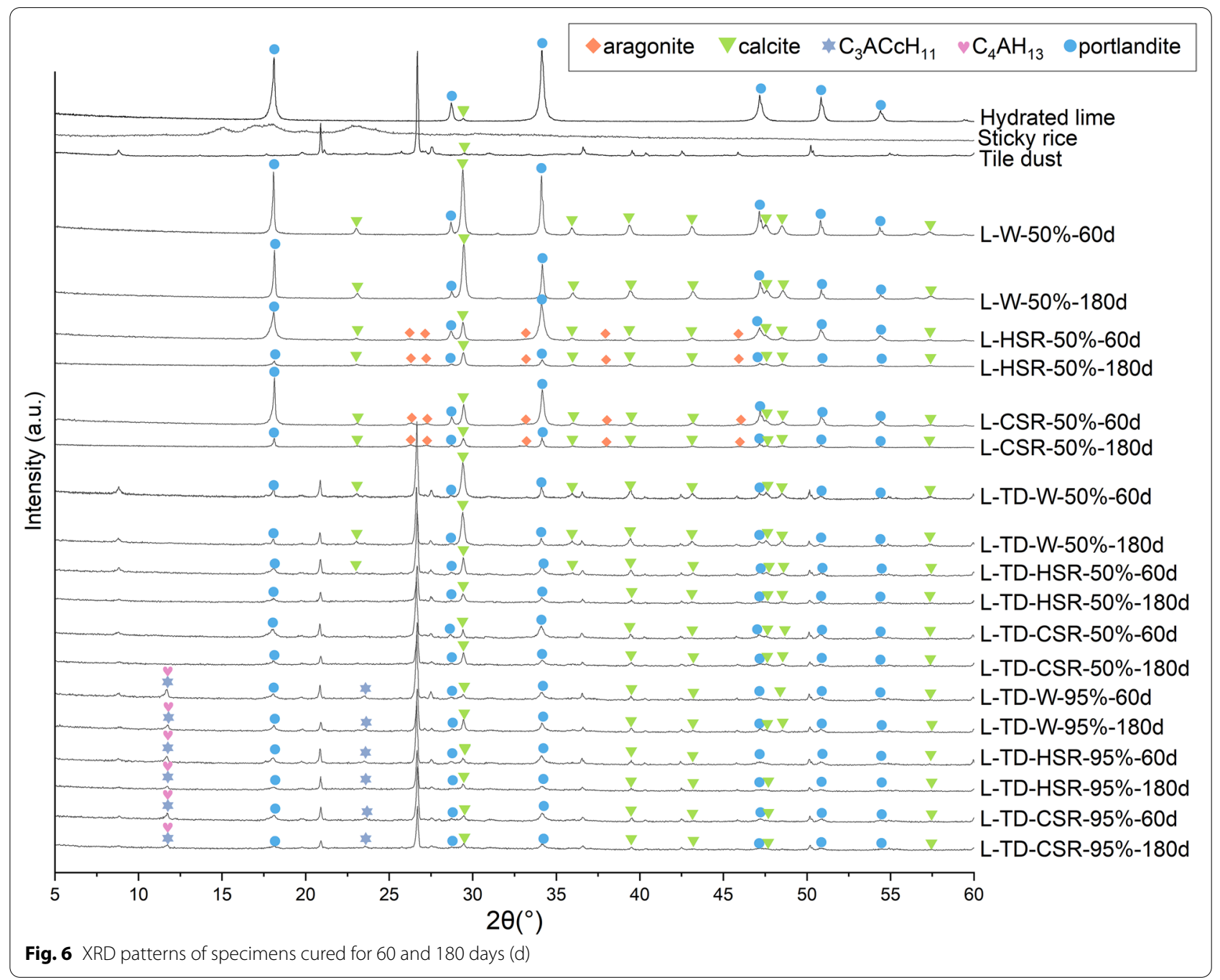


Table 7 Weight loss (\%) of raw materials and specimens after 60 and 180 days (d) of curing within different temperature ranges under $\mathrm{N}_{2}$ atmosphere in thermal analysis

\begin{tabular}{|c|c|c|c|c|c|}
\hline & $30-125^{\circ} \mathrm{C}$ & $125-200^{\circ} \mathrm{C}$ & $200-350^{\circ} \mathrm{C}$ & $350-450^{\circ} \mathrm{C}$ & $550-750^{\circ} \mathrm{C}$ \\
\hline Lime & 0.24 & 0.20 & 0.94 & 21.07 & 1.40 \\
\hline Tile dust & 0.22 & 0.19 & 0.42 & 0.25 & 0.77 \\
\hline Sticky rice & 10.48 & 0.52 & 60.47 & 7.66 & 2.01 \\
\hline L-W-50\%-60d & 0.89 & 0.41 & 0.85 & 8.22 & 27.45 \\
\hline L-W-50\%-180d & 0.57 & 0.20 & 0.75 & 6.09 & 31.53 \\
\hline L-HSR-50\%-60d & 2.06 & 0.64 & 4.61 & 12.69 & 15.48 \\
\hline L-HSR-50\%-180d & 1.36 & 0.36 & 5.85 & 6.34 & 29.68 \\
\hline L-CSR-50\%-60d & 1.81 & 0.65 & 5.02 & 9.95 & 22.38 \\
\hline L-CSR-50\%-180d & 1.23 & 0.40 & 5.68 & 5.8 & 30.62 \\
\hline L-TD-W-50\%-60d & 0.89 & 0.38 & 0.62 & 3.24 & 5.97 \\
\hline L-TD-W-50\%-180d & 0.79 & 0.35 & 0.53 & 2.22 & 9.32 \\
\hline L-TD-HSR-50\%-60d & 0.98 & 0.43 & 2.05 & 3.67 & 5.92 \\
\hline L-TD-HSR-50\%-180d & 0.88 & 0.31 & 2.15 & 2.36 & 9.12 \\
\hline L-TD-CSR-50\%-60d & 1.19 & 0.45 & 1.98 & 4.02 & 5.17 \\
\hline L-TD-CSR-50\%-180d & 0.78 & 0.24 & 1.97 & 2.22 & 9.40 \\
\hline L-TD-W-95\%-60d & 2.04 & 1.46 & 1.83 & 2.75 & 3.06 \\
\hline L-TD-W-95\%-180d & 3.08 & 1.65 & 2.03 & 2.19 & 1.84 \\
\hline L-TD-HSR-95\%-60d & 2.16 & 1.08 & 2.45 & 3.10 & 3.89 \\
\hline L-TD-HSR-95\%-180d & 2.68 & 1.11 & 2.35 & 2.4 & 3.86 \\
\hline L-TD-CSR-95\%-60d & 2.03 & 1.26 & 2.63 & 3.00 & 3.64 \\
\hline L-TD-CSR-95\%-180d & 2.80 & 1.22 & 2.51 & 2.54 & 3.17 \\
\hline
\end{tabular}

\section{TG-DSC}

Weight loss within $30-125{ }^{\circ} \mathrm{C}$ could be attributed to removal of physically adsorbed water. According to Table 7 and Fig. 7, under 50\% RH curing, specimens with sticky rice addition (L-HSR/CSR-50\%, L-TD-HSR/CSR$50 \%$ ) generally lost more weight than specimens without (L-W-50\%, L-TD-W-50\%), which should be caused by the moisture removal from the sticky rice powder $(10.48 \%$ $\mathrm{w} / \mathrm{w})$, possibly due to water molecules absorbed in the amorphous region [56]. On the contrary, under 95\% RH curing, L-TD-W-95\% (2.04 and 3.08\% at 28 and 180 days of curing) had similar weight loss values as L-TDHSR-95\% (2.16 and 2.68\%) and L-TD-CSR-95\% (2.03 and $2.80 \%$ ), which could be attributed to more $\mathrm{C}-\mathrm{S}-\mathrm{H}$ $\left(100-150{ }^{\circ} \mathrm{C}[73,76]\right)$ formed in L-TD-W-95\% and suggested the retarded pozzolanic reactions with sticky rice addition.

All specimens under dry curing showed little weight loss $(\leq 0.65 \%)$ within $125-200{ }^{\circ} \mathrm{C}$ throughout 180 days of curing (Table 7 and Fig. 7), while those cured under 95\% RH had more weight loss (1.08-1.65\%). Such phenomenon was more clearly reflected by the peaks at $\sim 115-$ $138{ }^{\circ} \mathrm{C}$ on the DTG and DSC curves of L-TD-W-95\%, L-TD-HSR-95\% and L-TD-CSR-95\% (Fig. 8). This weight loss should be due to hydration products [e.g. C-S-H $\left(100-150{ }^{\circ} \mathrm{C}[73,76], \mathrm{C}_{3} \mathrm{ACcH}_{11}\left(160-200{ }^{\circ} \mathrm{C}[77,78]\right)\right.$ and $\left.\mathrm{C}_{2} \mathrm{ASH}_{8}\left(180-230{ }^{\circ} \mathrm{C}[45,77]\right)\right]$ from the pozzolanic reactions facilitated under high relative humidity.

For specimens containing sticky rice (L-HSR/CSR-50\%, L-TD-HSR/CSR-50\%, L-TD-HSR/CSR-95\%), weight loss within $200-350{ }^{\circ} \mathrm{C}$ should be attributed to the depolymerization of sticky rice polysaccharides [79]. For lime-tile dust mortars cured under 95\% RH, a part of the weight loss within this temperature range could be attributed to: $\mathrm{C}_{4} \mathrm{AH}_{13}$ which decomposes at $220-265^{\circ} \mathrm{C}[76,80], \mathrm{AH}_{3}$ at $270-310{ }^{\circ} \mathrm{C}$ [69], and $\mathrm{C}_{3} \mathrm{AH}_{6}$ at $300-360^{\circ} \mathrm{C}[75,76]$.

Weight loss within $350-450{ }^{\circ} \mathrm{C}$ should be attributed to dehydration of $\mathrm{Ca}(\mathrm{OH})_{2}$ [81]. For specimens containing sticky rice, a part of the weight loss could still be caused by the depolymerization of polysaccharides. According to Rodriguez-Navarro et al. [55], within $100-395{ }^{\circ} \mathrm{C}$, an additional weight loss could be present, corresponding to thermal decomposition of organic additives adsorbed on portlandite crystals and/or distributed among such crystals. Additionally, DTG and DSC curves (Fig. 8) of specimens containing sticky rice $\left(\sim 400-422{ }^{\circ} \mathrm{C}\right)$ generally had lower decomposition temperatures than the specimens without $\left(\sim 411-430{ }^{\circ} \mathrm{C}\right)$, which might confirm the interaction/reaction between lime and sticky rice.

Within $550-750^{\circ} \mathrm{C}$, weight losses of the raw materials (hydrated lime (1.40\%), tile dust (0.77\%), and sticky rice powder $(2.01 \%)$ ) can be attributed to the carbonaceous 

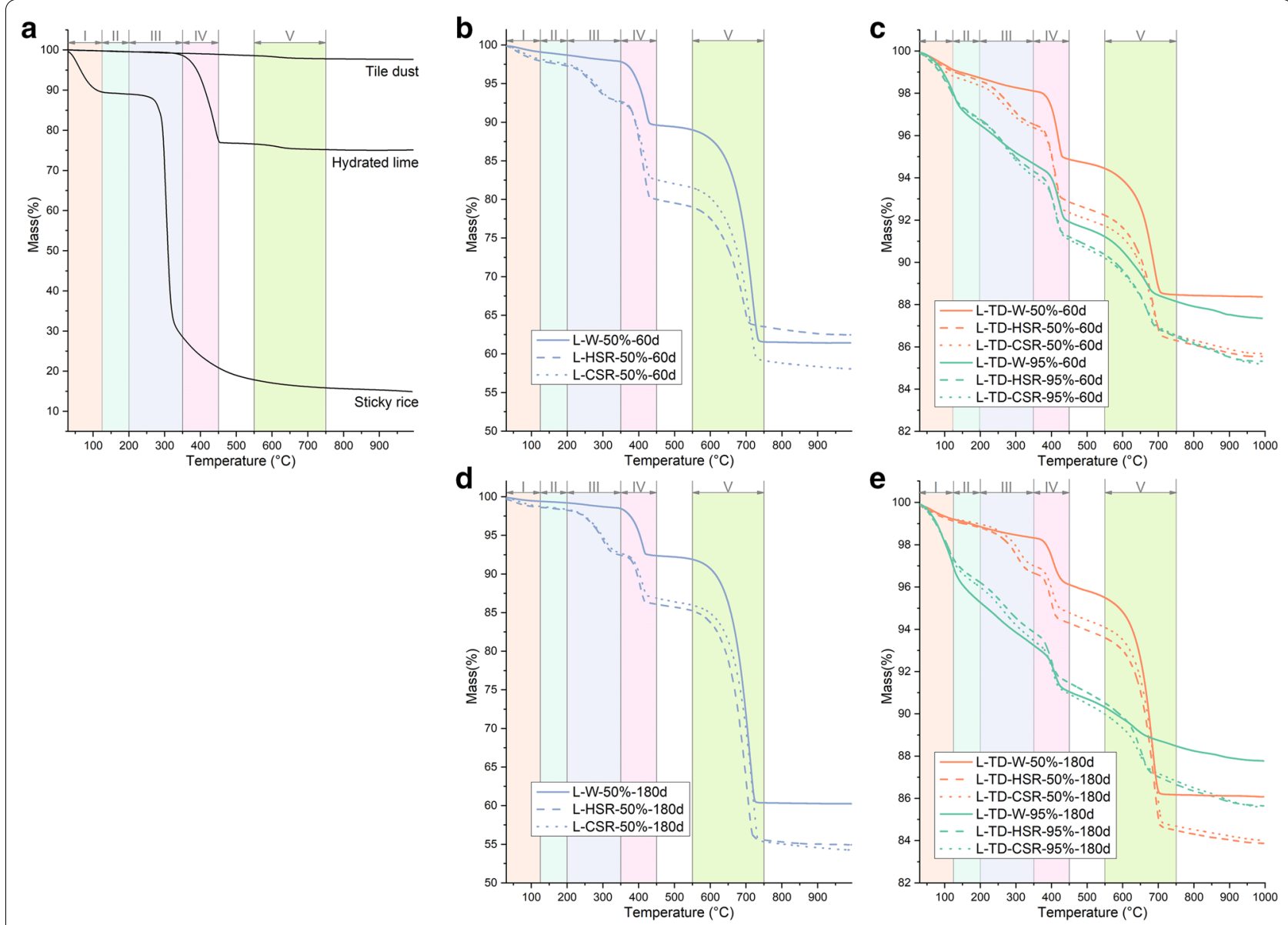

Fig. 7 TG curves of raw materials and specimens cured for 60 and 180 days (d). (Temperature range I: $30-125^{\circ} \mathrm{C} ;$ II: $125-200^{\circ} \mathrm{C} ;$ III: $200-350{ }^{\circ} \mathrm{C}$; IV: $350-450^{\circ} \mathrm{C} ; \mathrm{V}: 550-750^{\circ} \mathrm{C}$.)

matters in these materials (Table 7). Under $50 \% \mathrm{RH}$ curing for 60 days, the weight loss values of L-HSR$50 \%(15.48 \%)$ and L-CSR-50\% (22.38\%) were less than L-W-50\% (27.45\%). After 180 days of curing, however, the weight loss differences among L-W-50\%, L-HSR$50 \%$ and L-CSR-50\% (31.53, 29.68, 30.62\%, respectively) became little. It seemed that the addition of sticky rice porridge, especially at hot temperatures, could result in slower initial carbonation rate on lime mortars; then the specimen gradually carbonated throughout 6 months of curing, and finally achieved similar amounts of carbonates as in specimen L-W-50\%. The slower initial carbonation rate could be related to the decreased ion diffusion activities due to the confinement of lime particles inside sticky rice aquagel network. Additionally, according to Table 7, lime-tile dust mortar specimens cured under 50\% RH (L-TD-W-50\%, L-TD-HSR/CSR-50\%) had more weight loss within $550-750{ }^{\circ} \mathrm{C}$ than those cured under 95\% RH (L-TDW-95\%, L-TD-HSR/CSR-95\%), which shows that more carbonates were formed in the specimens cured under $50 \% \mathrm{RH}$. Air lime mortars gain strength through carbonation, as calcium carbonate forms and fills mortar pores and capillaries [82]. However, for the specimens cured under $95 \% \mathrm{RH}$, pozzolanic reactions between lime and tile dust were facilitated (which makes the mortar hydraulic), and such hydraulic lime mortars could usually result in higher mechanical strengths [20] than air lime mortars, as indicated by the compressive strength test results in the present study (Fig. 4).

\section{Conclusions}

The present study reported some preliminary effects of lime-tile dust mortars with sticky rice addition. Results showed that mortars with sticky rice porridge addition had higher water retention values, which could prevent excessive water loss and induce better mortar properties when applied on substrates. Addition of sticky rice porridge into mortars could decrease fresh and hardened mortar bulk density values under both 

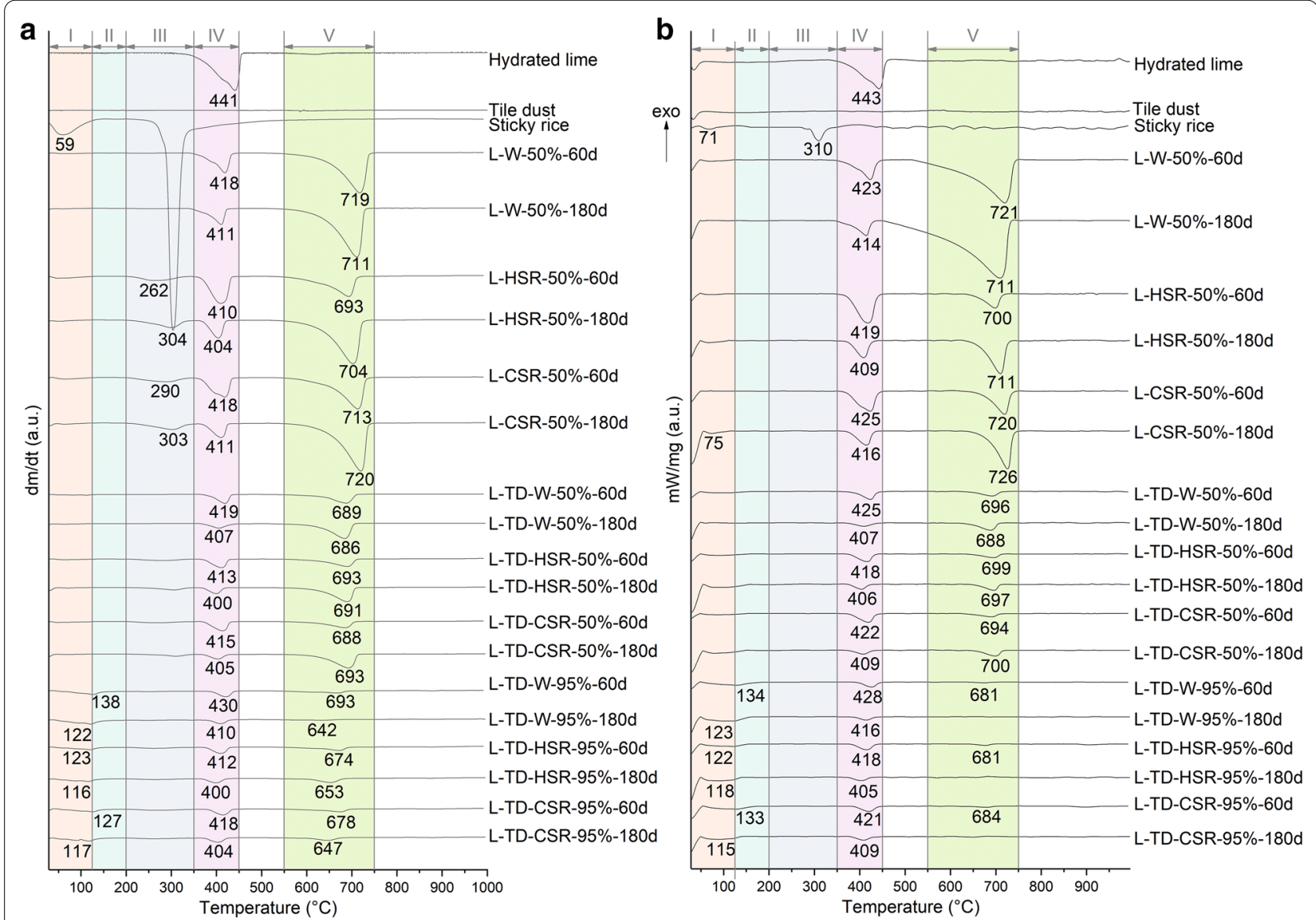

Fig. 8 a DTG and $\mathbf{b}$ DSC curves of a raw materials and specimens cured for 60 and 180 days (d). (Temperature range I: $30-125^{\circ} \mathrm{C} ; 11: 125-200{ }^{\circ} \mathrm{C} ; 111:$ 200-350 ${ }^{\circ} \mathrm{C}$; IV: $350-450^{\circ} \mathrm{C} ; \mathrm{V}: 550-750^{\circ} \mathrm{C}$.)

dry and humid curing, thereby increasing their water absorption values. However, by curing mortars under high relative humidity (95\% RH), their water absorption coefficient values could be reduced, especially over a long period of curing time (180 days). The addition of sticky rice into hydraulic lime mortars could slow down carbonation as well as hydration process (especially within the first 60 days of curing), which not only prolonged mortar setting time, but also impaired mortar strength development. Apart from calcite, aragonite was also formed as carbonation product.

\section{Acknowledgements}

The authors acknowledge the support from the research group of Wall Paintings on the Silk Road, School of Cultural Heritage, Northwest University.

\section{Authors' contributions}

KZ: methodology, experiment, data analysis, writing-original draft preparation. YS: experiment, data analysis. LW, FT: conceptualization, methodology. FY, YL: data interpretation, writing-reviewing and editing. YZ: writing-reviewing and editing. All authors read and approved the final manuscript.

\section{Funding}

This work was supported by Natural Science Foundation of China [Grant Number B0501 21975202]; China Postdoctoral Science Foundation [Grant Number 2020M673457]; Innovation Chain Project of Key Industries in Shaanxi province, China [Grant Number 2019ZDLSF07-05]; and Collaborative Innovation Team

Foundation of University in Gansu Province, China [Grant Number 2017C-20].

\section{Availability of data and materials}

The datasets used and/or analysed during the current study are available from the corresponding author on reasonable request.

\section{Competing interests}

The authors declare that they have no competing interests.

\section{Author details}

${ }^{1}$ School of Cultural Heritage, Northwest University, Xuefu Avenue 1.

Xi'an 710000, China. ${ }^{2}$ Key Laboratory for the Preservation and Conservation of Cultural Heritage of Education Ministry, Northwest University, Xi'an 710000, China. ${ }^{3}$ National Museum of China, Beijing 100006, China. ${ }^{4}$ Northwest University Museum, Xi'an 710000, China.

Received: 21 October 2020 Accepted: 14 December 2020

Published online: 07 January 2021 


\section{References}

1. Chen Z, Xu F, Song Z. 明经世文编 [Complete works from Ming dynasty (in Chinese)]. First ed. Beijing: Ping Lu Tang; 1643.

2. Xu G. 农政全书 [On agriculture (in Chinese)]. Beijing: Ping Lu Tang; 1639.

3. Fu Z. 行水金鉴 [Knowledge on flood control (in Chinese)]. Beijing: Wenyuan Library; 1792.

4. Xu Q. 读礼通考 [Annotations on rituals (in Chinese)]. Beijing: Wen Yuan Ge; 1792.

5. Xu J.洋防说略 [Basic knowledge on coast defense (in Chinese)]. Qing dynasty Guangxu 13th year ed. Beijing: Block-printed copy; 1887.

6. Li L. 晋陕、闽赣地域传统堡寨聚落比较研究 [Comparison of vernacular buildings between Shanxi-Shaanxi and Jiangxi-Fujian provinces (master thesis in Chinese)]. Tianjin: Tianjin University; 2004.

7. Xie H. 福建土楼夯土版筑的建造技艺 [Craftsmanship of ramming in Fujian Tulou (in Chinese)]. 住宅科技 [Residence technology (in Chinese)]. 2004;7:39-42.

8. Yang F, Zhang B, Ma Q. Study of sticky rice- lime mortar technology for the restoration of historical masonry construction. Acc Chem Res. 2010;43(6):936-44.

9. Zhao P, Jackson MD, Zhang Y, Li G, Monteiro PJ, Yang L. Material characteristics of ancient Chinese lime binder and experimental reproductions with organic admixtures. Constr Build Mater. 2015;84:477-88.

10. Zhang Q, Li B, Zeng Q, Deng J, Wang J, Yan D. Erosion of aerial lime and sticky rice mortars by cyclic wetting-drying and dilute sulfate acid actions. Advances in Cement Research. 2020;32(8):343-57.

11. Yang R, Li K, Wang L, Bornert M, Tao H. A micro-experimental insight into the mechanical behavior of sticky rice slurry-lime mortar subject to wetting-drying cycles. J Mater Sci. 2016;51(18):8422-33.

12. Zeng $Y$, Zhang $B$, Liang $X$. A case study and mechanism investigation of typical mortars used on ancient architecture in China. Thermochim Acta. 2008;473(1-2):1-6.

13. Hu Y, Wei G, Fang S, Li X, Zhang B. 骨料种类对糯米灰浆性能的影响 [Influence of aggregate type on the properties of traditional sticky ricelime mortar (in Chinese)]. 土木与环境工程学报(中英文) [Journal of Civil and Environmental Engineering (in Chinese)]. 2019;41(3):134-40.

14. Yang H, Che Y, Jiang H, Lin G, Wei D. 微纳米复合掺和料对传统糯米-石 灰砂浆强度的影响 [Effects of micron-nano-particles on traditional sticky rice- lime mortars (in Chinese)]. 中国农村水利水电 [China rural water conservancy and hydropower (in Chinese)]. 2015(6):109-11+15.

15. Fan J. 战守全书 [Encyclopedia on military defense]. Nanjing: Blockprinted copy; 1628-1644.

16. Mao Y. 武备志 [On military defense]. first ed. Beijing: Manuscript; 1621.

17. Xu G. 新法算书 [The new book on mathematics (in Chinese)]. Si Ku Quan Shu ed. Beijing: Wen Yuan Ge; 1792.

18. Wang Z. 王祯农书 [On agriculture by Zhen Wang]. Guangzhou: Guangya Publising House; 1899.

19. Carr JG. An investigation on the effect of brick dust on lime-based mortars. Philadelphia: University of Pennsylvania; 1995

20. Nežerka V, Slížková Z, Tesárek P, Plachý T, Frankeová D, Petráňová V. Comprehensive study on mechanical properties of lime-based pastes with additions of metakaolin and brick dust. Cem Concr Res. 2014;64:17-29.

21. Li F. 穆堂类稿 [Essays by Fu Li]. Beijing: Feng Guo Tang; 1747.

22. Song X. 宋氏家仪部 [Rituals of the Song family]. Shanghai: Block-printed copy; 1488-1505.

23. Song Y. 天工开物 [Exploitation of the works of nature]. First ed. Beijing: Manuscript; 1637

24. Jin F. 治河奏绩书 [Achievement on river regulation]. Si Ku Quan Shu ed. Beijing: Wenyuan Library; 1792.

25. Li S. 修防琐志 [Records on defense construction]. Beijing: Manuscript; 1855.

26. Fang G. 两浙海塘通志 [Records on the sea walls in Liangzhe area]. Beijing: Block-printed copy; 1748.

27. Chen Z. 永定河志 [Records on Yongding River]. Beijing: Manuscript; 1789

28. British Standards Institution. BS EN 1097-3 Determination of loose bulk density and voids. London: British Standards Institution; 1998.

29. Shaanxi Architecture Science Research Institute. JGJ/T70-2009 Standard for test method of performance on building mortar (in Chinese): Water absorption test. Beijing: Shaanxi Architecture Science Research Institute; 2009.
30. British Standards Institution. BS EN 480-2 Admixtures for concrete, mortar and grout-- Test methods: Determination of setting time. London: British Standards Institution; 2006.

31. British Standards Institution. BS EN 1015-6 Methods of test for mortar for masonry: Determination of bulk density of fresh mortar. London: British Standards Institution; 1999.

32. British Standards Institution. BS EN 1015-6 Methods of test for mortar for masonry: Determination of dry bulk density of hardened mortar. London: British Standards Institution; 1999.

33. BSI. BS EN 1925 Methods of test for mortar for masonry: determination of water absorption coefficient by capillarity. London: British Standards Institution; 1925. p. 1999.

34. Glenn GM, Klamczynski AK, Chiou B, Wood DF, Orts WJ, Imam SH. Lightweight Concrete Containing an Alkaline Resistant Starch-Based Aquagel. J Polym Environ. 2004;12(3):189-96.

35. Bulichen D, Kainz J, Plank J. Working mechanism of methyl hydroxyethyl cellulose (MHEC) as water retention agent. Cem Concr Res. 2012;42(7):953-9.

36. Jolicoeur C, Simard M. Chemical admixture-cement interactions: phenomenology and physico-chemical concepts. Cem Concr Compos. 1998;20:87-101.

37. Peschard A, Govin A, Pourchez J, Fredon E, Bertrand L, Maximilien S, et al. Effect of polysaccharides on the hydration of cement suspension. J Eur Ceram Soc. 2006;26(8):1439-45.

38. Pourchez J, Govin A, Grosseau P, Guyonnet R, Guilhot B, Ruot B. Alkaline stability of cellulose ethers and impact of their degradation products on cement hydration. Cem Concr Res. 2006:36(7):1252-6.

39. Tadros ME, Skalny J, Kalyoncu RS. Early hydration of tricalcium silicate. J Am Ceram Soc. 1976:59:344-7.

40. Thomas NL, Birchall JD. The retarding action of sugars on cement hydration. Cem Concr Res. 1983;13(6):830-42.

41. Crepy L, Petit J, Wirquin E, Martin P, Joly N. Synthesis and evaluation of starch-based polymers as potential dispersants in cement pastes and self leveling compounds. Cement Concr Compos. 2014;45:29-38.

42. Glenn GM, Miller RM, Orts WJ. Moderate strength lightweight concrete from organic aquagel mixtures. Ind Crops Prod. 1998;8(2):123-32.

43. 杨华山, 车玉君, 江华利, 林戈, 魏东. 微纳米复合掺和料对传统糯米石灰砂浆强度的影响. 中国农村水利水电. 2015(06):109-11+15.

44. Cizer Ö, Van Balen K, Van Gemert D, Elsen J. Competition between carbonation and hydration on the hardening of calcium hydroxide and calcium silicate binders. 1st WTA-International PhD Symposium "Building materials and building technology to preserve the built heritage." Leuven: WTA Publications; 2009. p. 353-68.

45. Cizer Ö, Van Balen K, Van Gemert D. Competition between hydration and carbonation in hydraulic lime and lime-pozzolana mortars. Adv Mater Res. 2010;133:241-6.

46. Kochova K, Schollbach K, Gauvin F, Brouwers HJ. Effect of saccharides on the hydration of ordinary Portland cement. Constr Build Mater. 2017;150:268-75.

47. Miliani C, Rosi F, Daveri A, Brunetti B. Reflection infrared spectroscopy for the non-invasive in situ study of artists' pigments. Appl Phys A. 2012;106(2):295-307

48. Gunasekaran S, Anbalagan G, Pandi S. Raman and infrared spectra of carbonates of calcite structure. J Raman Spectrosc. 2006;37(9):892-9.

49. Dembovska L, Bajare D, Ducman V, Korat L, Bumanis G. The use of different by-products in the production of lightweight alkali activated building materials. Constr Build Mater. 2017;135:315-22.

50. Anbalagan G, Prabakaran A, Gunasekaran S. Spectroscopic characterization of Indian standard sand. J Appl Spectrosc. 2010;77(1):86-94.

51. Jang JG, Lee H-K. Effect of fly ash characteristics on delayed high-strength development of geopolymers. Constr Build Mater. 2016:102:260-9.

52. Makreski P, Jovanovski G, Kaitner B. Minerals from Macedonia XXIV Spectra-structure characterization of tectosilicates. J Mol Struct. 2009;924-926:413-9.

53. Sivakumar S, Khatiwada CP, Sivasubramanian J. Studies the alterations of biochemical and mineral contents in bone tissue of mus musculus due to aluminum toxicity and the protective action of desferrioxamine and deferiprone by FTIR, ICP-OES, SEM and XRD techniques. Spectrochim Acta A. 2014;126:59-67. 
54. González A, Igarzabal CIA. Soy protein-Poly (lactic acid) bilayer films as biodegradable material for active food packaging. Food Hydrocoll. 2013;33(2):289-96.

55. Rodriguez-Navarro C, Ruiz-Agudo E, Burgos-Cara A, Elert K, Hansen EF. Crystallization and colloidal stabilization of $\mathrm{Ca}(\mathrm{OH})_{2}$ in the presence of nopal juice (Opuntia ficus indica): Implications in architectural heritage conservation. Langmuir. 2017;33:10936-50.

56. Kizil R, Irudayaraj J, Seetharaman K. Characterization of irradiated starches by Using FT-Raman and FTIR Spectroscopy. J Agric Food Chem. 2002;50(14):3912-8.

57. Barth A. Infrared spectroscopy of proteins. Biochim Biophys Acta Bioenerg. 2007;1767(9):1073-101.

58. Dankar I, Haddarah A, Omar FEL, Pujolà M, Sepulcre F. Characterization of food additive-potato starch complexes by FTIR and X-ray diffraction. Food Chem. 2018. https://doi.org/10.1016/j.foodchem.2018.03.138.

59. Xiong J, Li Q, Shi Z, Ye J. Interactions between wheat starch and cellulose derivatives in short-term retrogradation: rheology and FTIR study. Food Res Int. 2017;100(Pt 1):858.

60. Sekkal M, Dincq V, Legrand P, Huvenne JP. Investigation of the glycosidic linkages in several oligosaccharides using FT-IR and FT Raman spectroscopies. J Mol Struct. 1995;349:349-52.

61. Vetter W, Schreiner M. Characterization of pigment-binding media systems - comparison of non-invasive in-situ reflection FTIR with transmission FTIR microscopy. E-Preservation Sci. 2011;8:10-22.

62. Liu H, Zhao Y, Peng C, Song S, López-Valdivieso A. Lime mortars-The role of carboxymethyl cellulose on the crystallization of calcium carbonate. Constr Build Mater. 2018:168:169-77.

63. Gueta R, Natan A, Addadi L, Weiner S, Refson K, Kronik L. Local atomic order and infrared spectra of biogenic calcite. Angew Chem Int Ed. 2007;46(1-2):291-4.

64. Wang S, Wang S, Lu Z, Yao W, Liu B, Li B. Characterization of sticky-rice lime binders from old masonry relics in north China: The primary contribution for conservation. Constr Build Mater. 2020;250:118887.

65. Ventolà L, Vendrell M, Giraldez P, Merino L. Traditional organic additives improve lime mortars: New old materials for restoration and building natural stone fabrics. Constr Build Mater. 2011;25(8):3313-8.

66. Dickinson SR, Mcgrath KM. Aqueous Precipitation of Calcium Carbonate Modified by Hydroxyl-Containing Compounds. Cryst Growth Des. 2004;4(6):1411-8.

67. Tai $\mathrm{CY}$, Chen FB. Polymorphism of $\mathrm{CaCO} 3$, precipitated in a constantcomposition environment. AlChE J. 1998;44(8):1790-8.

68. Torréns-Martín D, Fernández-Carrasco L, Martínez-Ramírez S. Hydration of calcium aluminates and calcium sulfoaluminate studied by Raman spectroscopy. Cem Concr Res. 2013;47:43-50.
69. Madej D, Szczerba J, Nocuń-Wczelik W, Gajerski R, Hodur K. Studies on thermal dehydration of the hydrated $\mathrm{Ca}_{7} \mathrm{ZrAl}_{6} \mathrm{O}_{18}$ at different water-solid ratios cured at $60^{\circ} \mathrm{C}$. Thermochim Acta. 2013;569:55-60.

70. Dickinson SR, McGrath K. Quantitative determination of binary and tertiary calcium carbonate mixtures using powder X-ray diffraction. Analyst. 2001;126(7):1118-21.

71. Wang R, Wang P-M. Formation of hydrates of calcium aluminates in cement pastes with different dosages of SBR powder. Constr Build Mater. 2011;25(2):736-41.

72. Pera J, Amrouz A. Development of highly reactive metakaolin from paper sludge. Adv Cem Based Mater. 1998;7(2):49-56.

73. Arizzi A, Cultrone G. Aerial lime-based mortars blended with a pozzolanic additive and different admixtures: A mineralogical, textural and physicalmechanical study. Constr Build Mater. 2012;31:135-43.

74. Midgley H. Measurement of high-alumina cement-calcium carbonate reactions using DTA. Clay Miner. 1984;19(5):857-64.

75. Sepulcre-Aguilar A, Hernández-Olivares F. Assessment of phase formation in lime-based mortars with added metakaolin, Portland cement and sepiolite, for grouting of historic masonry. Cem Concr Res. 2010;40(1):66-76.

76. Billong N, Melo U, Njopwouo D, Louvet F, Bonnet J. Effect of mixture constituents on properties of slaked lime-metakaolin-sand mortars containing sodium hydroxide. Cem Concr Compos. 2009;31(9):658-62.

77. Aggelakopoulou E, Bakolas A, Moropoulou A. Properties of lime-metakolin mortars for the restoration of historic masonries. Appl Clay Sci. 2011;53(1):15-9.

78. Bruno P, Calabrese D, Di Pierro M, Genga A, Laganara C, Manigrassi D, et al. Chemical-physical and mineralogical investigation on ancient mortars from the archaeological site of Monte Sannace (Bari-southern Italy). Thermochim Acta. 2004;418(1):131-41.

79. Zohuriaan MJ, Shokrolahi F. Thermal studies on natural and modified gums. Polym Test. 2004;23(5):575-9.

80. Moropoulou A, Bakolas A, Aggelakopoulou E. Evaluation of pozzolanic activity of natural and artificial pozzolans by thermal analysis. Thermochim Acta. 2004;420(1):135-40.

81. Kroehong W, Sinsiri T, Jaturapitakkul C, Chindaprasirt P. Effect of palm oil fuel ash fineness on the microstructure of blended cement paste. Constr Build Mater. 2011;25(11):4095-104.

82. Moorehead D. Cementation by the carbonation of hydrated lime. Cem Concr Res. 1986;16(5):700-8.

\section{Publisher's Note}

Springer Nature remains neutral with regard to jurisdictional claims in published maps and institutional affiliations.

\section{Submit your manuscript to a SpringerOpen ${ }^{\circ}$ journal and benefit from:}

- Convenient online submission

- Rigorous peer review

- Open access: articles freely available online

- High visibility within the field

- Retaining the copyright to your article

Submit your next manuscript at springeropen.com 